\title{
Development of the High-Speed Running of Trains in Ukraine for Integration with the International Railway Network
}

\author{
Dmytro Kurhan, Mykola Kurhan, Nelya Hmelevska
}

Department of Transport Infrastructure, Dnipro National University of Railway

Transport named after Academician V. Lazaryan

Lazaryan st. 2, 49010 Dnipro, Ukraine

\{kurhan.d, mykolakurhan, hmelevnela\}@ diit.edu.ua

\begin{abstract}
Most European countries successfully solve the problem of national passenger transportation due to a significant increase in speed. Such measures are carried out both on existing railways through their modernization, and on specially built lines. Mass passenger transportation along the HSN has confirmed their extremely high reliability, safety, economic efficiency, ecological cleanness, and attractiveness for passengers. The creation of international networks based on the potentials of individual countries leads to the need for establishing the following operational and technical parameters of domestic high-speed railway lines, which would have operational compatibility with the TransEuropean HSN. The interconnection between the volume of passenger traffic with the specified factors allows to predict promising passenger flow and evaluate the effectiveness in the organization of high-speed running in a particular direction. The economic integration of countries in the European Union allows increasing passenger flows on international travel. This circumstance leads to the problem solution in connecting national high-speed highways into a single European network.
\end{abstract}

Keywords: railway; train traffic; high-speed network; Net Present Value

\section{Introduction}

One of the priority directions in the development of railway transport is increasing the speed of passenger trains and further implementing a rapid and over the medium term a high-speed running both in Ukraine and in traffic between Ukraine and Western Europe.

The first-priority problem that needs to be carried out in accordance with the National Transport Strategy of Ukraine [1] includes providing a comprehensive innovative development of transport, in particular by creating conditions for the implementation of the high-speed passenger running on railways (up to 
$400 \mathrm{~km} / \mathrm{h}$ ), the expedited delivery of high-value goods (up to $350 \mathrm{~km} / \mathrm{h}$ ), faster delivery of containers (not less than $200 \mathrm{~km} / \mathrm{h}$ ).

At all times, the travel speed was the only integral indicator that characterized the development of passenger transport and in general the level of engineeringtechnical and economic development of the society. The way has gone from establishing the record levels of speed and painstaking work on the adaptation of the railway to the movement with high speeds to the organization of constant rotation of high-speed trains.

\section{Review of the Literature}

Most European countries successfully solve the problem of national transportation due to a significant increase in speed. Such measures are carried out both on existing railways through their modernization, and on specially built lines [2-7].

According to the National Transport Strategy of Ukraine for the period up to 2030 , it is planned to provide conditions for the rapid traffic of passenger trains between regional centers from 160 to $200 \mathrm{~km} / \mathrm{h}$, and by 2030 - from 250 to 350 $\mathrm{km} / \mathrm{h}$. Also, it is expected the expedited delivery of high-value goods at a speed of up to $350 \mathrm{~km} / \mathrm{h}$ and creating conditions for faster delivery of containerized freight - up to $200 \mathrm{~km} / \mathrm{h}[8]$.

In solving the tasks of the first stage - the rapid traffic on existing lines of the railway is considered as an entire system consisting of devices and structures which because of the imperfection of the technical condition can limit the speed of trains on each particular section. Therefore, it is necessary to know the allowable speed of trains on each section of the railway, as well as the parameters of devices, according to which the railway should be rebuilt for the implementation of these speeds. Papers [9-11] describe suggestions concerning parameters definition for the reconstruction of the railway while implementing the rapid traffic of trains on the existing line.

The main criteria for choosing the direction of the way were grounded on a balanced accounting of such fundamentally important requirements as the maximum reduction in the length of $\mathrm{HSN}$, providing optimal technical, operational and structural characteristics of the line (reduction in the number of turns, large artificial structures, volumes of earthworks, demolition of buildings, etc.), reduction in areas of operational lands, providing normative ecological and sanitary requirements in the zone of HSN impact [12-14].

On the example of Chinese railways, there is a full assessment of speeds implemented during operation [15-17]. The articles offers indicators and an integrated structure for a comprehensive assessment of the working speed on the high-speed railway. 
The question about the accessibility of the railway corridor is interesting. In papers [18-20] it is noted that accessibility to the railway corridor is provided both by a conventional railway (CR) and high-speed railway (HSR). Studies illustrate the importance of CR and HSR coordination, evaluating and comparing the railway accessibility of the Shanghai-Hangzhou corridor (SH) in China and the Osaka-Nagoya corridor (ON) in Japan, the corridor of high-speed trains MadridBarcelona-French border.

Article [21] is devoted to the analysis of accessibility of high-speed railways in Korea. As tools for evaluation, a dispersion analysis test (ANOVA) and cartographic audit based on geographic information systems (GIS) are used.

Based on the analysis of perspective tasks, issues in the implementation of rapid traffic (161-200 km/h) of trains in Ukraine is subject to substantiation; application of rolling stock with forced bodies tilt of cars; construction of the new railway track of the European standard, which in its parameters can provide the implementation of high-speed $(250-350 \mathrm{~km} / \mathrm{h})$ traffic of trains.

\section{Methods and Results of the Research}

\subsection{Implementation Activities upon Passenger Trains Traffic with Speeds of 160-200 $\mathrm{km} / \mathrm{h}$ in Kyiv-Lviv and Kyiv-Odesa Directions}

To conduct research at various stages in the functioning of the railway, it (system) is divided into the subsystem of the $1^{\text {st }}$ level (station-to-station blocks, interstations), which, in turn, are divided into the subsystem of the $2^{\text {nd }}$ level (objects, barrier sites). Horizontal curves, defective artificial structures, areas of the weak roadbed, etc. act as barrier sites.

The authors in [22] reviewed the local optimization. It envisages the possibility of setting the maximum allowable speed not only within each station-to-station block, but also for each object (barrier site). The solution of such a problem is much more complicated because it is necessary to consider interdependent sections (objects). For such sections it is characteristic that reducing the train traffic time received on each section after removal of constraints in traveling speed is not equal to the advantage in time if authors remove all speed limits. That is, it is possible to obtain proved initial data only after carrying out tractive calculations at various combinations of removal of speed limits (eliminating barrier sites). 
Table 1 shows the summarized results of executed tractive calculations for three technical states: option 1 - the initial condition of the railway, option 2 reconstruction of the plan of the line, Option 3 - reconstruction of the plan and replacement of railroad switches on interstations for train handling with higher speeds.

Table 1

Results of tractive calculations for trains of various categories

\begin{tabular}{|c|c|c|c|c|c|c|c|c|}
\hline \multirow[t]{2}{*}{ Section } & \multirow{2}{*}{$\begin{array}{l}\text { Length, } \\
\mathrm{km}\end{array}$} & \multirow[t]{2}{*}{ Train type } & \multicolumn{2}{|c|}{ Option 1} & \multicolumn{2}{|c|}{ Option 2} & \multicolumn{2}{|c|}{ Option 3} \\
\hline & & & $\begin{array}{l}\text { Travel } \\
\text { time, } \\
\text { min. }\end{array}$ & $\begin{array}{l}\text { Average } \\
\text { speed, } \\
\mathrm{km} / \mathrm{h}\end{array}$ & $\begin{array}{l}\text { Travel } \\
\text { time, } \\
\text { min. }\end{array}$ & $\begin{array}{l}\text { Average } \\
\text { speed, } \\
\mathrm{km} / \mathrm{h}\end{array}$ & $\begin{array}{l}\text { Travel } \\
\text { time, } \\
\text { min. }\end{array}$ & $\begin{array}{l}\text { Average } \\
\text { speed, } \\
\mathrm{km} / \mathrm{h}\end{array}$ \\
\hline \multirow[t]{3}{*}{ Kyiv-Fastiv } & \multirow{3}{*}{63.83} & Passenger & 79.1 & 96.8 & 77.1 & 99.4 & 77.1 & 99.4 \\
\hline & & Intercity+ & 60.7 & 126.3 & 56.3 & 136.1 & 51.3 & 149.3 \\
\hline & & Pendolino & 59.5 & 128.8 & 55.9 & 137.0 & 50.8 & 150.8 \\
\hline \multirow[t]{3}{*}{ Fastiv-Kozyatyn } & \multirow{3}{*}{95.16} & Passenger & 114.2 & 100.0 & 113.7 & 100.5 & 113.7 & 100.5 \\
\hline & & Intercity+ & 80.2 & 142.4 & 77.9 & 146.6 & 72.0 & 158.6 \\
\hline & & Pendolino & 79.8 & 143.2 & 77.5 & 147.3 & 71.4 & 159.9 \\
\hline \multirow{3}{*}{$\begin{array}{l}\text { Kozyatyn- } \\
\text { Zhmerynka }\end{array}$} & \multirow{3}{*}{109.48} & Passenger & 135.1 & 97.3 & 134.9 & 97.4 & 134.9 & 97.4 \\
\hline & & Intercity+ & 104.4 & 125.8 & 100.2 & 131.1 & 88.3 & 148.8 \\
\hline & & Pendolino & 103.9 & 126.4 & 98.3 & 133.6 & 85.9 & 152.9 \\
\hline \multirow{3}{*}{$\begin{array}{l}\text { Zhmerynka- } \\
\text { Pidvolochysk }\end{array}$} & \multirow{3}{*}{165.87} & Passenger & 205.2 & 97.0 & 201.4 & 98.8 & 201.4 & 98.8 \\
\hline & & Intercity+ & 155.0 & 128.4 & 143.4 & 138.8 & 138.1 & 144.1 \\
\hline & & Pendolino & 150.6 & 132.2 & 137.0 & 145.3 & 130.2 & 152.9 \\
\hline \multirow{3}{*}{$\begin{array}{l}\text { Pidvolochysk- } \\
\text { Ternopil }\end{array}$} & \multirow{3}{*}{52.94} & Passenger & 69.4 & 91.5 & 65.4 & 97.1 & 65.4 & 97.1 \\
\hline & & Intercity+ & 57.0 & 111.5 & 51.7 & 122.9 & 50.6 & 125.6 \\
\hline & & Pendolino & 53.5 & 118.7 & 47.6 & 133.5 & 45.8 & 138.7 \\
\hline \multirow[t]{3}{*}{ Ternopil-Krasne } & \multirow{3}{*}{90.10} & Passenger & 117.2 & 92.3 & 111.6 & 96.9 & 111.6 & 96.9 \\
\hline & & Intercity+ & 104.4 & 103.6 & 87.3 & 123.8 & 85.3 & 126.8 \\
\hline & & Pendolino & 100.4 & 107.7 & 81.4 & 132.8 & 78.4 & 137.9 \\
\hline \multirow[t]{3}{*}{ Krasne-Lviv } & \multirow{3}{*}{50.98} & Passenger & 67.2 & 91.0 & 63.3 & 96.6 & 63.3 & 96.6 \\
\hline & & Intercity+ & 55.2 & 110.8 & 47.2 & 129.6 & 44.6 & 137.2 \\
\hline & & Pendolino & 51.5 & 118.8 & 44.7 & 136.9 & 41.9 & 146.0 \\
\hline \multirow[t]{3}{*}{ Kyiv - Lviv } & \multirow{3}{*}{628.36} & Passenger & 787.4 & 95.8 & 767.3 & 98.3 & 767.3 & 98.3 \\
\hline & & Intercity+ & 616.9 & 122.2 & 564.0 & 133.7 & 530.2 & 142.2 \\
\hline & & Pendolino & 599.2 & 125.8 & 542.4 & 139.0 & 504.4 & 149.5 \\
\hline
\end{tabular}

The required capital investments to perform work on the modernization of infrastructure and reconstruction of the plan of the line are presented (Fig. 1) in the form of such components: track works, contact network and traction substations, reconstruction and modernization of signalling control devices, construction and reconstruction of passenger facilities at running lines and stations: railway stations, foot bridges, platforms, etc. 


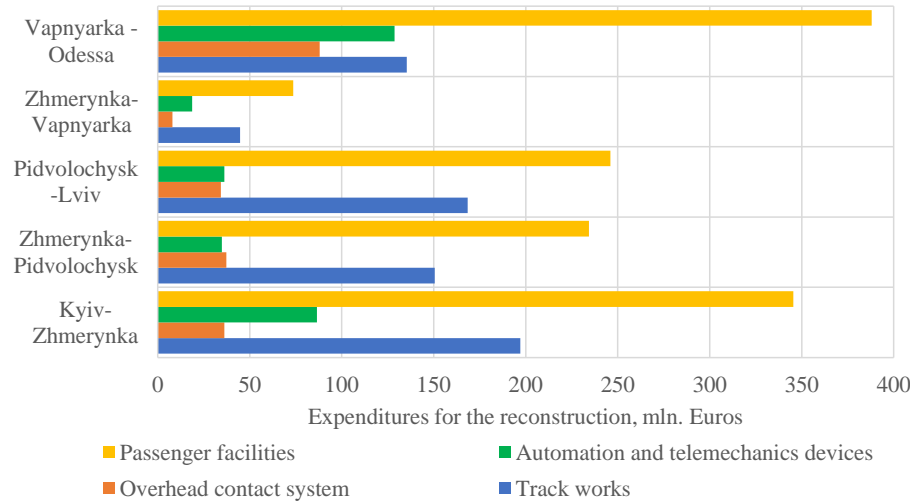

Figure 1

Expenses for the reconstruction of Odesa-Kyiv-Lviv direction

The total costs amounted to 2.5 million Euros $/ \mathrm{km}$ (74.8 million UAH/km), which was adopted for the next assessment of the design decision.

\subsection{Application of Rolling Stock with the Forced Bodies Tilt of Cars}

One of the common ways to increase the speed of trains in the curved track is the use of rolling stock with a forced bodies tilt of cars. Trains such as "Pendolino" run in Italy, France, Great Britain, Spain, Portugal, Austria, Czech Republic, Slovenia, etc. Optimistic predictions that the purchase of rolling stock with the forced bodies tilt of cars will solve the issue of increasing the traffic speed in curves by $25-40 \%$ compared to the trains of locomotive traction without investing in the development of the railway infrastructure in real conditions may be incorrect. This is attested by the results of the above studies $[3,5,9]$.

The conclusion that rolling stock with a forced bodies tilt of cars passes with a larger by $25-45 \%$ speed compared to a conventional passenger train was obtained by the non-exceedance criterion of the allowable level of unbalanced acceleration within one circular curve acting at the passenger, without taking into account other factors. The presence of fitted curves, short transition curves and steep grade due to elevation of the outer rail does not allow to provide a high speed on the sections of the track and the reduction of motion time in average is $10-15 \%$.

Thus, after the reconstruction on the Kyiv-Lviv section (see Table 1), the average passenger train speed will be $98 \mathrm{~km} / \mathrm{h}$, Intercity+ train $-142 \mathrm{~km} / \mathrm{h}$, Pendolino train - is about $150 \mathrm{~km} / \mathrm{h}$, which is 1.5 times higher compared to passenger and $5 \%$ higher compared to Intercity+. Accordingly, the travel time will be 12.8 hours, 8.8 hours and 8.4 hours. 
Based on the above, it can be concluded that a technique of adjusting a slope angle of a car body can not be an alternative to existing railways with the complex plan of the line. Using Pendolino Trains can lead to a tangible advantage in time at the train traffic, if authors consider the option of the new route with the corresponding parameters of the curves.

\subsection{The Engineering of the New Route to Ensure Transportation by High-Speed Transport}

In order to develop the network of railways in Ukraine, a systematic approach that envisaged the design and construction of new high-speed railways and modernization and reconstruction of existing ones was introduced.

In 2016, the predictive update program for rolling stock for the period up to 2021 was prepared including the section: "Organization of high-speed running". The Kyiv-Lviv-state border direction with the countries of Western Europe with further integration of the line with the European Network of the HSN is proposed to be the primary direction in the implementation of high-speed running in Ukraine (up to $350 \mathrm{~km} / \mathrm{h}$ ). The next stages in the implementation of projects for construction of HSN can be directions: Kyiv-Odesa; Kyiv-Poltava-KharkivDonetsk; Kyiv-Poltava-Dnipro.

If the railroads can be included in HSN where a speed of $250 \mathrm{~km} / \mathrm{h}$ and higher is realized, then the length of such railways in the world is about 110 thousand $\mathrm{km}$, of which $53 \%$ and $47 \%$ are in operation at the stage of new and modernization of existing railways.

At the low percent of HSN in the total length of main railways (China $-29.0 \%$, Spain $-25.0 \%$, Taiwan $-22.0 \%$, Japan $-11.7 \%$, France $-11.7 \%$ ), the volume of passenger work performed by them many times exceeds the total volume of passenger transportation. It indicates high competitiveness and demand in this type of transport [23]. Figure 2 shows countries in alphabetical order.

Today there are many scientific research devoted to the study of ways for the further development of the Trans-European high-speed railway network. One of these projects is NGT (Next Generation Train) developed by eight Institutes in the German Aerospace Center (DLR). The main idea of NGT is to determine the HSN ground in Europe, calculated at the movement of new generation trains (NGT) at a speed of $400 \mathrm{~km} / \mathrm{h}$.

According to research [16], there are four types of operating models. They can be identified in various high-speed rail systems, which are currently working around the world, and their connection with ordinary rail systems.

The first type of model is characterized by a complete separating from traditional services, it is used in Japan. 


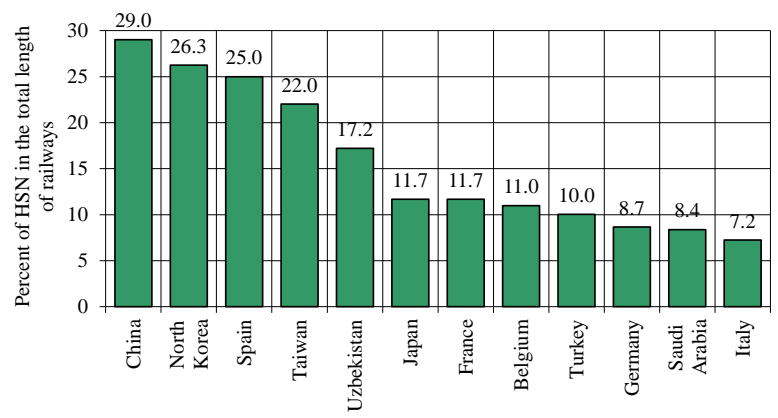

Figure 2

HSN in the total length of railways

The second model of exploitation is a mixed high-speed model in which a rapid train can move both on a specially built new line, and on upgraded sections of ordinary lines, which ultimately leads to a reduction in construction costs. This model is in agreement with the French system TGV (Train à Grande Vitesse).

The third model of operation is a mixed conventional model adopted in the Spanish rail system, it allows handling of some ordinary trains along the highspeed railways.

The fourth model is a fully mixed model. It involves using both high-speed, and ordinary trains on one infrastructure. This model is used for the German ICE system, where high-speed trains use upgraded ordinary lines, and freight trains - a reserve crossing capacity on the high-speed lines at night.

Thus, it can be considered advisable to build the new electrified double-track railroad in a length of $900 \mathrm{~km}$, specialized for the movement of high-speed passenger transport and faster delivery of container and high-value goods. At the same time, high-speed trains can go to the existing Odesa-Kyiv-Lviv line to service them at the existing passenger stations, but trains of the existing railway are forbidden to go on the high-speed line. Travel time is 1.5-2.0 hours, route speed is about $270 \mathrm{~km} / \mathrm{h}$.

\section{Performance Evaluation of Design Decisions}

The essential factors determining the success of the HSN projects are the economic indicators of the country's development, as well as the financial position of citizens living in the HSR load region. The interconnection between the volume of passenger traffic with these factors allows to predict a promising passenger flow and evaluate the effectiveness in the organization of high-speed running on a particular direction. As world practice and calculations show, the construction of 
the HSR can be effective in Ukraine in directions when the population of the load region is 20-25 million people, the length of the line does not exceed $800-900 \mathrm{~km}$, and passenger flow is not less than 5-6 million people per year.

The authors analysed the dynamics, the main trends of passenger transportation and calculated flow factors [24]. Designed in long-distance traffic, the flow factor is significantly different in the regions and ranges from 0.9 to 2.28; On average, it is about 1.5 trips per year.

Methods are taken as the basis of the preliminary assessment of the project's efficiency [25-27] in accordance with which this assessment can be performed by six indicators. Authors turn our attention to the most common NPV (Net Present Value of Discounted Cash Flow) which is a difference of aggregate income and all types of expenses taking into account the factor of time.

For comparison of options: the reconstruction of the existing railway, the implementation of rolling stock with the construction of the European track and the implementation of high-speed running in Ukraine. The authors developed a model for predicting and evaluating the efficiency of rail transportation, taking into account all expenses by the $N P V$ indicator [23, 28].

The analysis of the results showed that with the cost of reconstruction for OdesaKyiv-Lviv infrastructure $(1010 \mathrm{~km})$ of 2.5 million euro/km, the organization of rapid traffic will be economically justified at annual volumes of freight traffic 1015 million tons and volumes of passenger traffic 15-20 pairs of trains per day.

To determine the most optimum compromise of high-speed passenger and specialized freight transportation on the new route, various combinations were considered. The issue of choosing the track gauge when designing a new railway remains relevant. The choice of 1,520 $\mathrm{mm}$ or $1,435 \mathrm{~mm}$ track gauge for use on the Ukrainian network is one of the most important issues. Each option has both negative and positive factors [29].

In the construction of the European standard railway $(900 \mathrm{~km})$ with the implementation of rolling stock with titling trains, the net present value depends on the volume of freight and passenger transportation and the cost of $1 \mathrm{~km}$ of the new railway. As it is seen from the graph (Fig. 3), the largest economic effect and in the shortest term can be achieved with the volumes of specialized freight transportation of 20-25 million tons per year $(G)$ and passenger transportation of 15-20 pairs of trains per day $(n)$. According to the results of tractive calculations in the Kyiv-Odesa and Kyiv-Lviv directions, the delivery time will be about 2 hours without taking into consideration the time to stop at a route speed of about $220 \mathrm{~km} / \mathrm{h}$.

In the construction of a railway of the Ukrainian standard with the implementation of high-speed rolling stock, type TGV POS, the net present value also depends on the volume of freight and passenger transportation and cost of $1 \mathrm{~km}$ of the new railway (Fig. 4). As it follows from the graph, the largest economic effect and in 
the shortest term can be achieved with the volumes of special freight traffic 25-30 million tons per year $(G)$ and passenger transportation 15-20 pairs of trains per day $(n)$. According to the results of tractive calculations, the delivery time of passengers on the Kyiv-Odesa and Kyiv-Lviv sections will be about 1.5 hours without taking into account time to stop at a route speed of $280 \mathrm{~km} / \mathrm{h}$.

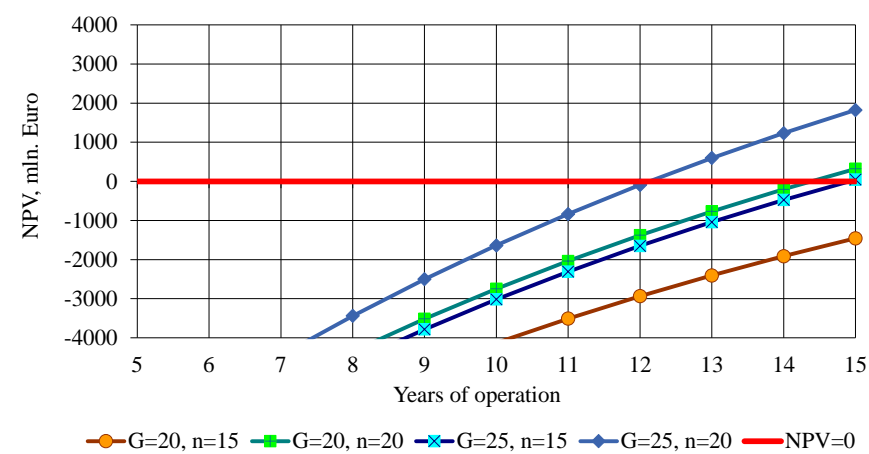

Figure 3

The term when the net present value arises depending on the volume of freight and passenger transportation in the construction of a new railroad with a track gauge of $1,435 \mathrm{~mm}$

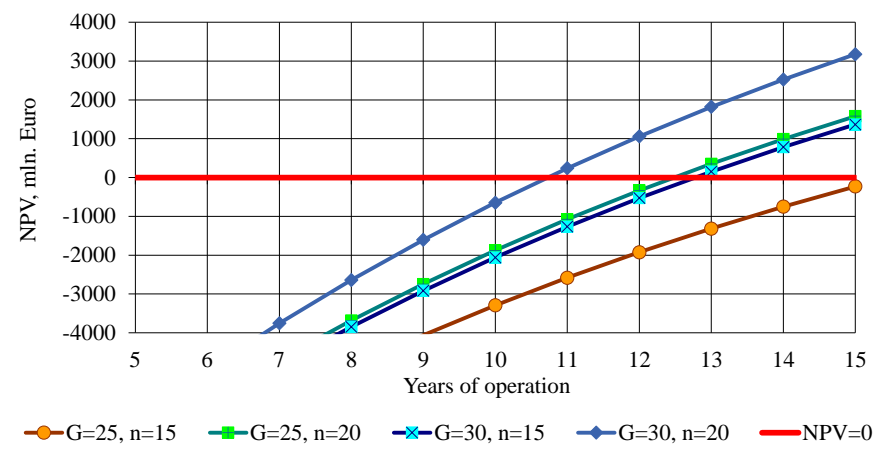

Figure 4

The term when the net present value arises depending on the volume of freight and passenger transportation in the construction of a new railway track with a track gauge of $1,520 \mathrm{~mm}$

\section{Conclusions}

The creation of international networks based on the potentials of individual countries leads to the need for establishing the following operational and technical parameters of domestic high-speed railway lines, which would have operational compatibility with the Trans-European HSN. 
The essential factors determining the HSN projects' success are the economic indexes of the national development, as well as the financial position of citizens living in the HSN load area. The interconnection between the volume of passenger traffic with the specified factors allows to predict promising passenger flow and evaluate the effectiveness in the organization of high-speed running in a particular direction. As evidenced by world practice and the performed calculations, the construction of the HSN can be effective in Ukraine in directions when the population of the load area is 20-25 million people, the length of the line does not exceed $800-900 \mathrm{~km}$, and passenger traffic is not less than 5-6 million people per year. When designing the HSN, a new independent route must be laid in the shortest distance, without entering the main same cities, which allows relying on electricity savings, a decrease in ecological damage, to reduce the time of passengers staying by 2-3 times. To serve the population of cities and transfer of passengers to other types of transport one should be provided with technological connections of it with the existing general network of railways with the entry of the part of expresses to reconstructed stations in the central part of cities.

The construction of the proposed network of high-speed railways in Ukraine should be carried out in several stages. Implementation of the first stage (it is performed) will ensure the introduction of high-speed running between Kyiv and the main regional cities: Kharkiv, Dnipro, Lviv, Odesa, etc. The task of the second stage is to create a network of high-speed highways with technical and operational parameters that provide the motion of high-speed express trains at a speed of up to $350 \mathrm{~km} / \mathrm{h}$. The implementation of the HSM in Ukraine requires significant investments for the construction of transport infrastructure and the purchase of rolling stock. Many issues arise with the land allotment for construction, the cost of land plots, the possibility of private capital participation, construction organization.

The implementation of rapid traffic on the territory of Ukraine together with rapid lines Kyiv-Lviv, Kyiv-Odesa, Kyiv-Kharkiv, Kyiv-Dnipro will allow creating a single network of rapid traffic that will be attractive to users, which in turn will increase the number of transit passengers in the directions of the West - Ukraine North East. The economic integration of countries in the European Union allows increasing passenger flows on international travel. This circumstance leads to the problem solution in connecting national high-speed highways into a single European network.

\section{References}

[1] National transport strategy of Ukraine for the period up to 2030. https://mtu.gov.ua/news/28581.html [online, last visited on: 2021.09.30]

[2] R. Pittman, M. Jandová, M. Król, L. Nekrasenko, T. Paleta. The effectiveness of EC policies to move freight from road to rail: Evidence from CEE grain markets. Research in Transportation Business \& Management, Vol. 37, 2020, 100482 
[3] G. Bureika, L. Bielousova, V. Nozhenko. Estimation of Ecological Effectiveness of Rail Vehicle Operation in Eurasian Railway Corridors. Transport Means, 2019, pp. 460-465

[4] A. Németh, S. Fischer. Investigation of glued insulated rail joints applied to CWR tracks. Facta Universitatis Series Mechanical Engineering, 2021, 7642

[5] A. Massel. Train Commercial Speed Versus Maximum Line Speed Central-European Experience. Transport Means, 2019, pp. 358-366

[6] A. Massel, A. Soczówka. Evolution of High-Quality Express Passenger Train Services in Poland in 1989-2019. Transport Means 2020, pp. 49-56

[7] R. Pittman. Reforming and restructuring Ukrzaliznytsia: a crucial task for Ukrainian reformers. Science and Transport Progress, Vol. 1(67), 2017, pp. $34-50$

[8] A. Shevchenko, O. Matviienko, V. Lyuty, V. Manuylenko. M. Pavliuchenkov. Ways of introduction of the high-speed movement of passenger trains in Ukraine. MATEC Web Conf. 230, 2018, 01014

[9] S. Fischer. Comparison of railway track transition curves. Pollack Periodica, Vol. 4(3), 2009, pp. 99-110

[10] I. Lebid, I. Kravchenya, T. Dubrovskaya, N. Luzhanska, M. Berezovyi, Y. Demchenko. Identification of the railway reconstruction parameters at imposition of high speed traffic on the existing lines. MATEC Web of Conferences 294, 2019, 05003

[11] O. Hubar, R. Markul, O. Tiutkin, V. Andrieiev, M. Arbuzov, O. Kovalchuk. Study of the interaction of the railway track and the rolling stock under conditions of accelerated movement. IOP Conf. Ser.: Materials Science and Engineering, Vol. 985, 2020, 012007

[12] O. M. Pshinko, L. V. Ursulyak, K. I. Zhelieznov, A. O. Shvets. To the problem of train running safety. IOP Conf. Ser.: Materials Science and Engineering, 985, 2020, 012014

[13] M. Kurhan, D. Kurhan. Problems of providing international railway transport. MATEC Web of Conf., 230, 2018, 01007

[14] K. Grębowski, M. Zielińska. Dynamic Analysis of Historic Railway Bridges in Poland in the Context of Adjusting Them to Pendolino Trains. International Journal of Applied Mechanics and Engineering, Vol. 20(2), 2015, pp. 283-297

[15] J. Zhang, J. Zhang. Comprehensive Evaluation of Operating Speeds for High-Speed Railway: A Case Study of China High-Speed Railway. Mathematical Problems in Engineering, Vol. 1, 2021, pp. 1-16 
[16] D. Sun, S. Zeng, H. Ma, J. J. Shi. How Do High-Speed Railways Spur Innovation? IEEE Transactions on Engineering Management, 2021

[17] China's High-Speed Rail Technology. Zhejiang University Press, Hangzhou and Springer Nature Singapore Pte Ltd., 2018, 587 p.

[18] A. Li, J. Liua, H. Katoc, Q. Peng. Accessibility for a railway corridor integrating high-speed railway and conventional railway. Transportation Research Board Annual Meeting, 2021

[19] J. Jiao, J. Wang, F. Jin. Impacts of High-Speed Rail Lines on the City Network in China. Journal of Transport Geography, Vol. 60, 2017, pp. 257 266

[20] S. L. Shaw, Z. Fang, S. Lu, R. Tao. Impact of high speed rail on the rail network Accessibility in China. Journal of Transport Geography, Vol. 40, 2014, pp. 112-122

[21] J. S. Chang, J.-H. Lee. Accessibility Analysis of Korean High-speed Rail: A Case Study of the Seoul Metropolitan Area. Transport Reviews, Vol. 28(1), 2008, pp. 87-103

[22] M. B. Kurhan, D. M. Kurhan. Scientific-technical support of the railway Ukraine - European Union. Dnipro, Ukraine, 2018, 268 p.

[23] M. B. Kurhan, D. M. Kurhan. Theoretical bases for introduction of highspeed train operation in Ukraine. Dnipro, Ukraine, 2016, 283 p.

[24] M. Kurhan, D. Kurhan. Forecasting of Passenger Traffic upon Implementation of High-Speed Running. Science and Transport Progress. Vol. 67(1), 2017, pp. 117-130

[25] Dac Criteria for Evaluating Development Assistance https://www.oecd.org/dac/evaluation/49756382.pdf [online, last visited on: 2021.09.30]

[26] Results-Based Management approach as applied at UNESCO https://unesdoc.unesco.org/ark:/48223/pf0000177568 [online, last visited on: 2021.09.30]

[27] Guide to Cost-Benefit Analysis of Investment Projects. https://ec.europa.eu/regional_policy/sources/docgener/studies/pdf/cba_guid e.pdf [online, last visited on: 2021.09.30]

[28] M. Kurhan, D. Kurhan. Providing the railway transit traffic UkraineEuropean Union. Pollack Periodica, Vol. 14(2), 2019, pp. 27-38

[29] M. Kurhan, D. Kurhan, M. Husak, N. Hmelevska. Perspectives of Highspeed Train Traffic in Ukraine at the Stage of Integration with the European Network. Transport Means, 2021 